\title{
A simple, precise, and sensitive HPLC method for quantification of letrozole in rat plasma: development, validation, and preclinical pharmacokinetics
}

\author{
Aswathi R. Hegde, Bharat Singh Padya, Soji Soman and Srinivas Mutalik *i]
}

\begin{abstract}
A simple bioanalytical liquid chromatographic method was developed and validated to quantify letrozole (LTZ) in rat plasma. Protein precipitation using acidified chilled acetonitrile (containing $0.1 \%$ orthophosphoric acid) was used to extract LTZ from the plasma. Chromatographic separation was carried out on Kinetex C18 reverse phase (RP) column $(250 \mathrm{~mm} \times 4.6 \mathrm{~mm}$ i.d., $5 \mu \mathrm{m})$ using a mixture of $20 \mathrm{mM}$ acetate buffer ( $\mathrm{pH} \mathrm{5.5)}$ and acetonitirile $(60: 40 \% \mathrm{v} /$ v) eluting at $1.0 \mathrm{~mL} / \mathrm{min}$ flow rate with the method responses measured at $240 \mathrm{~nm}$. The optimized method was selective and established good linearity with recovery ranging between 91.16 and $99.44 \%$. The validation experiments revealed that the method showed acceptable precision (2.61-7.48\%) and accuracy (97.44-102.70\%) and was found to be stable. The sensitivity of the method was demonstrated by the lowest concentration (LLOQ) detected at $75 \mathrm{ng} / \mathrm{mL}$. Using the developed method, single-dose oral pharmacokinetics in Sprague-Dawley rats was carried out to successfully confirm the applicability of the method for the quantification of LTZ in biological matrix.
\end{abstract}

Keywords: Letrozole, Bioanalytical, Validation, Rat plasma, Protein precipitation, Chromatographic

\section{Introduction}

A majority of the breast cancers are hormone dependent, of which estrogen plays an important role. Estrogen synthetase or aromatase is the catalytic enzyme involved in the local biosynthesis of estrogens from androgens. Exposure to circulating estrogen levels leads to the increased risk of developing breast cancer. Hence, inhibition of aromatase enzyme to reduce the peripheral conversion to estrogen is an attractive strategy in the therapy of hormone-dependent breast cancer (Chumsri et al. 2011). Conversion of androgens to estrogen can be effectively stopped by aromatase inhibitors (AIs), which block the aromatase enzyme thus impairing the growth and development of tumors (Osborne and Tripathy

\footnotetext{
*Correspondence: ss.mutalik@manipal.edu; ssmutalik@yahoo.com Department of Pharmaceutics, Manipal College of Pharmaceutical Sciences, Manipal Academy of Higher Education, Manipal, Karnataka State 576104,
} India

2005; Scott and Keam 2006). Letrozole (LTZ) is a po, non-steroidal, 3rd generation AI used to treat the brand name Femara ${ }^{\circ}$ to treat local or metastatic and metabolizes to form the is inactive and further excreted in the urine (Acharjya t al. 2012) zas et al. 2003; Mareck et al. 2005; Mondal et al. 2007; Laha et al. 2008). In this regard, we have previously reported a sensitive, robust, and stable analytical liquid 
chromatographic (RP-HPLC) method to estimate LTZ in bulk and in nanoformulations (Hegde et al. 2018).

For the quantification of LTZ (either alone or in combinations) in biological fluids, several analytical methodologies have been reported. Previously, a few spectrophotometric methods have been developed to estimate LTZ; however, these methods are not very sensitive and accurate to quantify LTZ in low concentrations (Mondal et al. 2007; Ganesh et al. 2007; Ganesh et al. 2008). Fluorescence detection has been reported to quantify LTZ in human plasma and urine (Marfil et al. 1996; Zarghi et al. 2007). However, these solid-phase extraction methods resulted in longer retention times and time-consuming processing. Pfister et al. reported an enzyme immunoassay (EIA) and HPLC method for the quantification of LTZ in the plasma. While the EIA method was non-specific and resulted in cross-reactivity of metabolites, the HPLC method was based on liquid-liquid extraction, which was tedious and had low sensitivity (Pfister et al. 1994). The liquid chromatographic method utilizing MS-MS systems has been used for the analysis of LTZ letrozole in plasma, which are sensitive and selective with a low level of quantification. However, such methods require operation by trained personnel and sophisticated equipment (Joshi et al. 2011; AlShehri et al. 2019; Vanol et al. 2016). Acharjya et al. reported a fast and sensitive liquid chromatographic method using liquid-liquid extraction for the estimation of LTZ in the serum (Acharjya et al. 2012). However, the method reported a shorter retention time with observable interference corresponding to drug retention time. Recently, Dhakne et al. reported a simultaneous liquid chromatographic method for the simultaneous quantification of LTZ and abemaciclib in rat plasma using the liquid-liquid extraction method for extracting the drug from the plasma (Dhakne et al. 2020). However, the separation of analytes follows a gradient technique, which requires a dwell period for adjusting the column condition, in addition to significantly longer run times due to postgradient re-equilibration of the column (Marina and Garcia 2000).

Hence, in the present study, we present an accurate, sensitive, and reproducible RP-HPLC method to quantify LTZ in rat plasma. The proposed method is simple and economic over the previously reported methods as we employed an isocratic mode of elution that is highly efficient, utilizing protein precipitation technique for the extraction of drug from the plasma. The method was developed and validated in accordance with the USFDA guidelines. In addition, the optimized method was applied to determine the pharmacokinetics of LTZ in healthy female Sprague-Dawley (SD) rats.

\section{Methods}

Materials and reagents

Letrozole (LTZ) was a kind gift sample from Gland Pharma Ltd., Malur, Karnataka, India. Carbamazepine (CBZ), ketoconazole (KCZ), and paracetamol (PA), which were used as internal standard (IS), were obtained from Sun Pharmaceutical Industries Ltd., Vadodara, India, and Kumar Organic Products Ltd., Bengaluru, India. Ammonium acetate, glacial acetic acid, and methyl tertbutyl ether (MTBE) were procured from Spectrochem Pvt. Ltd., Mumbai, India. Ortho-phosphoric acid (OPA) and acetonitrile (ACN) were procured from Merck Ltd. (Mumbai, India). Methanol of HPLC grade was acquired from Finar Ltd. (Ahmedabad, India). Potassium dihydrogen orthophosphate was purchased from Sisco Research Laboratories Pvt. Ltd (Mumbai, India). Ultrapure water used in the preparation of sample and mobile phase was obtained from a Millipore Direct- $Q^{\circ} 3$ water purification system (Millipore Corporation, MA, USA).

\section{Animals}

The experiments were carried out in SD rats (weighing 200-250 g). Before commencing the study, approval was sought from the Institutional Animal Ethical Committee, Manipal, India (Approval No.: IAEC/KMC/76/2020). The animals were handled according to the institutional and national guidelines for the use and care of animals.

\section{Instrumentation and chromatographic specifications}

The chromatographic separation of LTZ was effected using a HPLC system (Shimadzu, Kyoto, Japan) equipped with LC-10 AD pump, CBM-20A Prominence system controller (Shimadzu, Kyoto, Japan), DGU-20A5 degasser unit, and SIL-10AXL auto-injector. The responses were recorded using SPD-10A UV-Vis detector and analyzed using LC Solution 5.57 system control (Hegde et al. 2018). A mixture of $20 \mathrm{mM}$ acetate buffer $(\mathrm{pH} 5.5)$ and $\mathrm{ACN}(60: 40 \% \mathrm{v} / \mathrm{v})$ was used to separate LTZ and IS on a Kinetex C18 column maintained $25^{\circ} \mathrm{C}$ column temperature and $10^{\circ} \mathrm{C}$ autosampler temperature. Samples was eluted at a flow rate of $1.0 \mathrm{~mL} / \mathrm{min}$, and the run time for each sample was set to $12 \mathrm{~min}$. Twenty microliters of the sample was injected into the HPLC and analyzed at a detector wavelength of $240 \mathrm{~nm}$.

\section{Extraction procedure}

Extraction of drug and IS from rat plasma was performed by protein precipitation technique. Ninety microliters of clear plasma, $10 \mu \mathrm{L}$ of LTZ $(10 \mu \mathrm{g} / \mathrm{mL})$, and $10 \mu \mathrm{L}$ of CBZ $(50 \mu \mathrm{g} / \mathrm{mL})$ were mixed using a vortex mixer (CM101, Remi Equipment, Mumbai, India). This mixture was acidified using OPA $(0.1 \% \mathrm{v} / \mathrm{v})$ and further vortexed for $2 \mathrm{~min}$. Later, the volume was made up using 
chilled $\mathrm{ACN}$ as a precipitating agent and centrifuged at $15,000 \mathrm{rpm}$ and $10^{\circ} \mathrm{C}$ for $10 \mathrm{~min}$ in a cold centrifuge (Hegde et al. 2017). The clear supernatant was removed, and $20 \mu \mathrm{L}$ was injected into the HPLC.

\section{Preparation of quality control (QC) samples and spiked samples}

Initially, a primary stock solution of LTZ standard $(500 \mu \mathrm{g} / \mathrm{mL})$ was prepared by weighing LTZ $(5 \mathrm{mg})$ and dissolved in methanol $(5 \mathrm{~mL})$ in a volumetric flask (10 $\mathrm{mL}$ ). The final volume was made up using methanol. Aliquots of primary stock solution were further diluted to make a series of dilutions. Standard solution of IS $(500 \mu \mathrm{g} / \mathrm{mL})$ was prepared by adding CBZ $(5 \mathrm{mg})$ in methanol $(5 \mathrm{~mL})$ in a volumetric flask $(10 \mathrm{~mL})$, and the volume was made up using methanol. Further dilutions were made to get a working standard solution of $50 \mu \mathrm{g} /$ $\mathrm{mL}$ concentration.

For plasma linearity, LTZ standard solutions having concentrations viz. $0.075,0.1,0.25,0.5,0.75,1,2.5,5$, and $10 \mu \mathrm{g} / \mathrm{mL}$ were prepared. The least detectable quantity in the plasma, also called lower limit of quantification (LLOQ), was observed at $75 \mathrm{ng} / \mathrm{mL}$. Known concentrations of LTZ standard solutions were spiked with plasma and extracted following protein precipitation to obtain low quality control (LQC; $0.225 \mu \mathrm{g} / \mathrm{mL}$ ), middle quality control (MQC; $1 \mu \mathrm{g} / \mathrm{mL}$ ), and high quality control (HQC; $8 \mu \mathrm{g} / \mathrm{mL}$ ) samples.

\section{Method optimization}

Several buffers such as acetate buffer $\mathrm{pH} 4.5$, acetate buffer $\mathrm{pH}$ 6.0, and phosphate buffer $\mathrm{pH} 3.0$ were trialed. Varying mobile phase compositions comprising buffer and acetonitrile were evaluated to achieve optimum separation of drug and IS. Active pharmaceutical ingredients such as PA, KCZ, and CBZ were screened for the selection of IS. To achieve maximum drug extraction, protein precipitation as well as liquid-liquid extraction was trialed. Chilled ACN containing $0.1 \% \mathrm{v} / \mathrm{v}$ OPA was used as precipitating solvent to precipitate proteins from the plasma whereas liquid-liquid extraction was carried out using solvents such as diethyl ether, ethyl acetate, and MTBE (Acharjya et al. 2012; Dhakne et al. 2020).

\section{Method validation}

After optimizing the chromatographic method based on optimum separation, satisfactory peak shape, and good resolution between the analytes, validation of the developed method was performed as per the USFDA guidelines for the following recommended parameters (Managuli et al. 2017).

\section{System suitability}

The method suitability was assessed by injecting six replicates of LTZ solution $(1 \mu \mathrm{g} / \mathrm{mL})$ and evaluating the system suitability parameters.

\section{Selectivity}

Three replicates each of diluent (mobile phase), blank plasma, and spiked plasma were injected separately to assess the specificity of the method. The absence of interference at the $\mathrm{R}_{\mathrm{t}}$ of LTZ and IS due to diluent or blank plasma indicates that the method passes the selectivity test.

\section{Linearity}

Linearity was established by spiking known concentrations of LTZ solution with plasma to obtain a series of concentrations ranging from 0.075 to $10 \mu \mathrm{g} / \mathrm{mL}$. The peak area ratio of drug/IS versus drug concentrations was plotted to establish the regression equation. Accuracy and precision of the calibration standards were determined by back calculating the drug concentrations from the regression equation.

\section{Precision and accuracy}

Inter- and intra-day precision and accuracy runs were carried out at LQC ( $\mathrm{n}=6)$, MQC $(\mathrm{n}=6)$, and HQC (n $=6$ ) by injecting the spiked samples into HPLC.

\section{Recovery}

For recovery studies, the percent drug recovery was calculated at LQC, MQC, and HQC by comparing the area ratios of extracted analytes with those of unextracted analytes (indicating 100\% recovery).

\section{Stability studies}

Short-term stability studies were determined by storing LQC and HQC samples (three replicates each) at normal room temperature (RT) for 7 days followed by analysis using HPLC. Freeze-thaw stability studies were determined by freezing the LQC and HQC samples at $-20^{\circ} \mathrm{C}$ for $24 \mathrm{~h}$ and further thawing at RT. Upon complete thawing, the samples were again kept at $-20^{\circ} \mathrm{C}$ for $12 \mathrm{~h}$. This freeze-thaw cycle continued thrice after which a sample analysis was carried out at the end of the third cycle. For benchtop stability studies, spiked plasma QC levels (LQC and HQC) were kept on benchtop for $8 \mathrm{~h}$, following which the samples were injected. Autosampler stability was assessed by storing the processed LQC and HQC samples in the autosampler for $10 \mathrm{~h}$ at $10^{\circ} \mathrm{C}$. Standard stock solution stability of LTZ and IS was assessed by keeping the samples on benchtop for $24 \mathrm{~h}$ at RT followed by analysis using HPLC. 


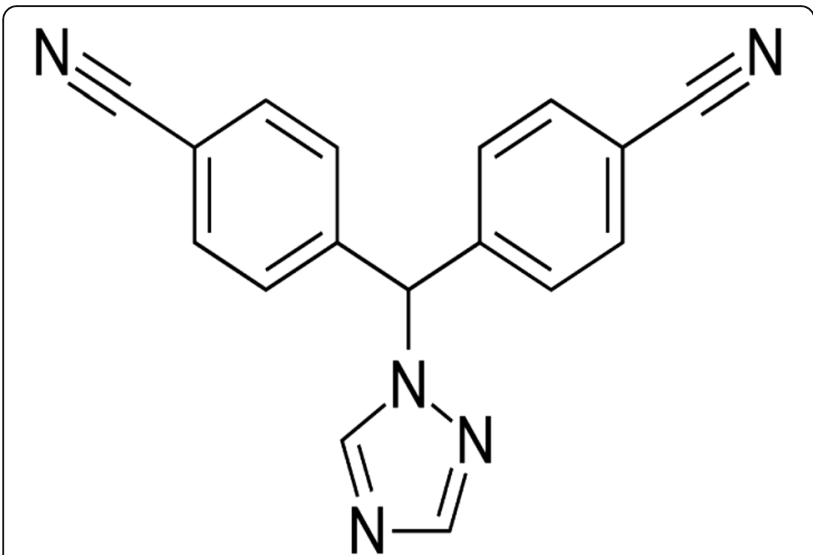

Fig. 1 Molecular structure of letrozole (LTZ)

\section{Pharmacokinetics study}

The applicability of the developed bioanalytical method was assessed by carrying out the pharmacokinetic studies in female SD rats. Before commencing the study, rats were housed in polypropylene cages and quarantined for a week to acclimatize with the environmental conditions. An air-conditioned room $\left(25 \pm 2{ }^{\circ} \mathrm{C}\right)$ was used to keep the cages, and the animals were exposed to light and dark cycles (12 h each).

For the pharmacokinetic study, rats $(n=6)$ were dosed with LTZ at $2 \mathrm{mg} / \mathrm{kg}$ body weight. Following oral administration, blood $(0.4 \mathrm{~mL})$ was withdrawn by retro-orbital puncture at intervals of $0.5,1,2,4,6$, $12,24,36$, and $72 \mathrm{~h}$ into 2-mL Eppendorf tubes containing $20 \mu \mathrm{L}$ disodium EDTA solution. Clear plasma was separated by centrifuging the samples at 10,000 rpm for $8 \mathrm{~min}$ at $4{ }^{\circ} \mathrm{C}$. Until analysis, all plasma samples were stored at $-80^{\circ} \mathrm{C}$ until analysis. The amount of LTZ present in the plasma was quantified using
HPLC, and the pharmacokinetic parameters were determined using the Winonlin software.

\section{Results and discussion Method optimization}

Considering the pKa (2.17) of LTZ (Fig. 1), buffer having a $\mathrm{pH}>3$ was used as the mobile phase. Based on previous literature, drugs such as paracetamol (PA), ketoconazole (KCZ), and carbamazepine (CBZ) were trialed to select a suitable internal standard (IS) with optimum retention time, favorable resolution, and good peak shape (Al-Shehri et al. 2019; Dhakne et al. 2020). The stationary phase comprised Kinetex C18 column $(250 \times 4.6$ $\mathrm{mm}, 5 \mu$ ). The results of the optimization trials with PA and $\mathrm{KCZ}$ as IS are given in Fig. S1 and Fig. S2 (supplementary information).

Being an extremely basic drug with a pKa value of 2.3, CBZ was used as the IS, to assess the elution of LTZ by liquid-liquid extraction using MTBE. Initially, trials were carried out using acetate buffer $\mathrm{pH} 4.5$ and $\mathrm{ACN}$ in the ratio $(50: 50 \% \mathrm{v} / \mathrm{v})$ eluting at a flow rate of $1 \mathrm{~mL} / \mathrm{min}$. Drug and IS were extracted from the plasma using liquid-liquid extraction with MTBE. Following injection, it was observed that the drug peak was distorted in addition to significant interference with plasma (Fig. 2). Hence, additional trials were carried out by changing the $\mathrm{pH}$ of the mobile phase to 5.5 based on the results observed with other IS (supplementary information). The mobile phase comprised a combination of acetate buffer pH 5.5 and $\mathrm{ACN}(60: 40 \% \mathrm{v} / \mathrm{v})$ flowing at $1.0 \mathrm{~mL} / \mathrm{min}$. The peaks of LTZ and CBZ were well resolved with an $R_{t}$ of $7.02 \mathrm{~min}$ and $5.23 \mathrm{~min}$, respectively. No interference was observed at $R_{t}$ of drug or IS when compared to blank plasma. An additional trial was carried out using the protein precipitation technique (using chilled ACN

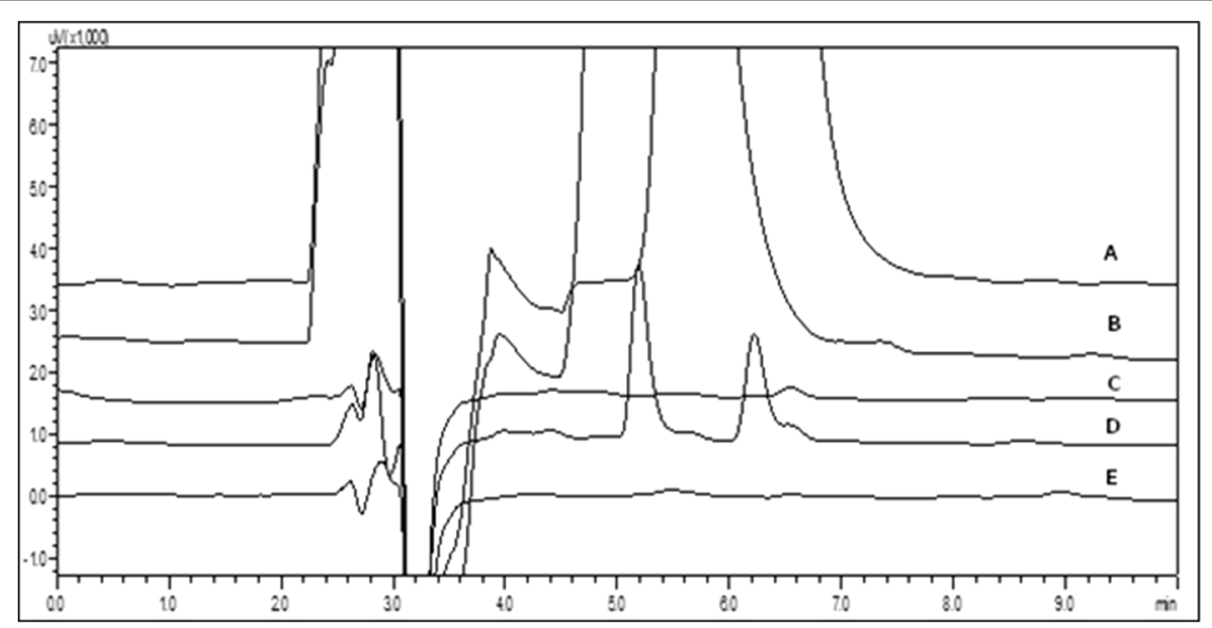

Fig. 2 Effect of mobile phase composition and CBZ (IS). Chromatograms of (A) LTZ, (B) CBZ, (C) blank plasma, (D) spiked plasma, and (E) diluent using $\mathrm{ACN}$ and acetate buffer $\mathrm{pH} 4.5(50: 50 \% \mathrm{v} / \mathrm{v})$ at $1 \mathrm{~mL} / \mathrm{min}$ 


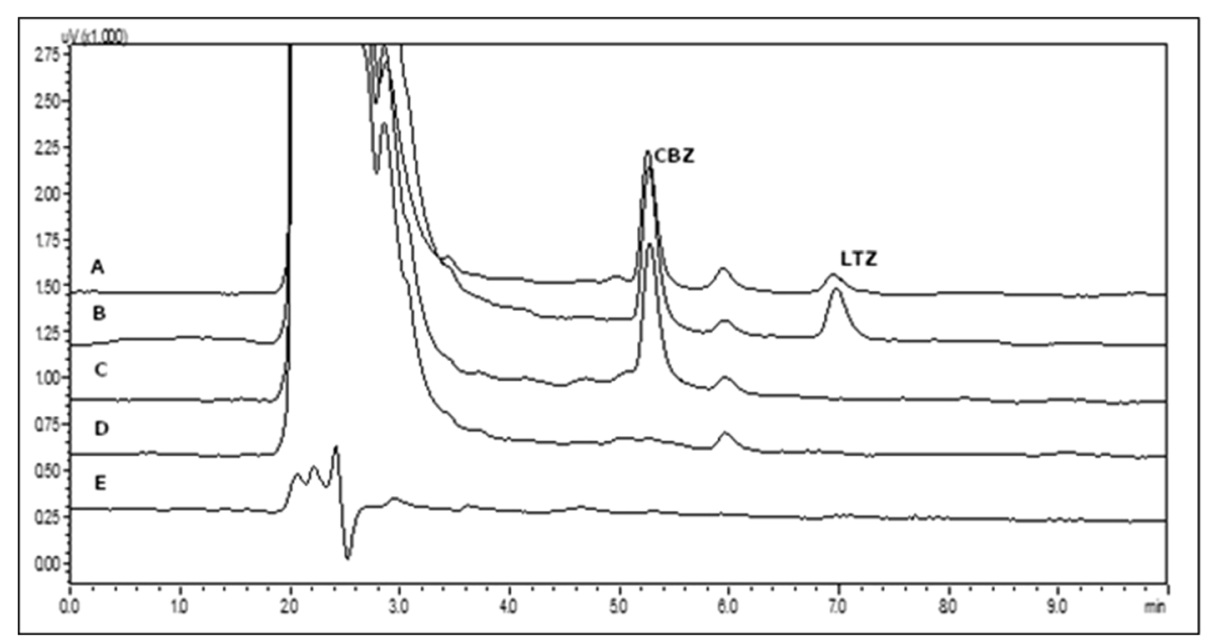

Fig. 3 Chromatograms of plasma samples and diluent eluted using the optimized chromatographic method. (A) Plasma sample from pharmacokinetic study, (B) plasma spiked with LTZ and CBZ, (C) plasma spiked with CBZ, (D) blank plasma, and (E) diluent

and $0.1 \% \mathrm{v} / \mathrm{v}$ OPA) to extract the analytes in the plasma. Protein precipitation technique is very suitable for biological matrices such as the whole blood, serum, or plasma. Since the recovery of the analytes was comparable in both the techniques of extraction, it was decided to use protein precipitation considering that it is simple, economical with minimal loss of sample, and can be adapted for a wide range of chemistries (Bylda et al. 2014; Stone 2017). In addition, the inclusion of OPA as the acidic agent further aided the process of precipitation due to the interaction with proteins in the plasma leading to the formation of an insoluble salt. Compared to the methods reported previously, the novelty of the present method is the use of a simple drug extraction method with rapid cleanup of the sample.

Hence, the optimized method comprised a mobile phase mixture containing $\mathrm{ACN}$ and $20 \mathrm{mM}$ ammonium acetate buffer pH $5.5(60: 40 \% \mathrm{v} / \mathrm{v})$ eluted at $1.0 \mathrm{~mL} / \mathrm{min}$, maintained at $25^{\circ} \mathrm{C}$ column temperature and $10^{\circ} \mathrm{C}$ autosampler temperature. Drug and IS (CBZ) were extracted by protein precipitation from plasma matrix using acidified $(0.1 \% \mathrm{v} / \mathrm{v}$ OPA) chilled ACN. Samples were injected at $20 \mu \mathrm{L}$, and the total run time was set to $12 \mathrm{~min}$ with method responses measured at $240 \mathrm{~nm}$. This resulted in the optimum separation of LTZ at $R_{t}$ of $7.02 \mathrm{~min}$ and CBZ at $5.23 \mathrm{~min}$ with a $\mathrm{Tf}_{10 \%}$ of 1.4 (LTZ) and 1.3
(CBZ) with a plate count (N) of 5639 (LTZ) and 6145 (CBZ) (Fig. 3).

\section{Method validation}

The optimized method was validated in accordance with the USFDA guidelines (US Department of Health and Human Services, Food and Drug Administration 2018) for various validation parameters.

\section{System suitability}

The method was found to be suitable for the intended application, which was demonstrated by the compliance of the system suitability parameters with the acceptance criteria. The relative standard deviation (RSD) of the peak area for LTZ was observed to be $1.4 \%(<2.0 \%)$ with a $\mathrm{Tf}_{10 \%}$ of $1.2(<2.0)$ and a plate count $(\mathrm{N})$ of $5639(>2000)$.

\section{Selectivity}

No interference of the diluent or blank plasma was observed at the $\mathrm{R}_{\mathrm{t}}$ of drug or IS which indicates the specificity of the proposed method (Fig. 3). In addition, the peak area in the blank plasma was $<20 \%$ compared to the peak area of the LLOQ sample at the $R_{t}$ of the drug. The LLOQ was observed at $0.075 \mu \mathrm{g} / \mathrm{mL}$, which indicates the sensitivity of the chromatographic method.

Table 1 Precision and accuracy data for the estimation of LTZ in rat plasma

\begin{tabular}{|c|c|c|c|c|c|c|c|c|}
\hline \multirow{2}{*}{$\begin{array}{l}\text { QC } \\
\text { level }\end{array}$} & \multicolumn{4}{|l|}{ Inter-day } & \multicolumn{4}{|l|}{ Intra-day } \\
\hline & Mean conc. detected $(\mu \mathrm{g} / \mathrm{mL})$ & SD & CV (\%) & Accuracy (\%) & Mean conc. detected $(\mu \mathrm{g} / \mathrm{mL})$ & SD & CV (\%) & Accuracy (\%) \\
\hline$\overline{L Q C}$ & 0.219 & 0.014 & 6.34 & 94.02 & 0.217 & 0.016 & 7.48 & 95.52 \\
\hline MQC & 1.037 & 0.056 & 5.44 & 102.13 & 1.030 & 0.063 & 6.14 & 103.62 \\
\hline $\mathrm{HQC}$ & 7.653 & 0.200 & 2.61 & 95.00 & 7.657 & 0.234 & 3.05 & 94.91 \\
\hline
\end{tabular}

HQC high quality control, MQC middle quality control, LQC low quality control, SD standard deviation, $C V$ coefficient of variance 
Though a few previous reports have shown better sensitivity, these methods demonstrated very short retention times for LTZ which is not desirable (Al-Shehri et al. 2019; Zarghi et al. 2007). The sensitivity of the present method is considerably more compared to previous reports where LLOQ was observed at $0.15 \mu \mathrm{g} / \mathrm{mL}$ and $0.1 \mu \mathrm{g} / \mathrm{mL}$ (Acharjya et al. 2012; Dhakne et al. 2020).

\section{Linearity}

The developed method demonstrated good linearity between the concentration range $0.075-10 \mu \mathrm{g} / \mathrm{mL}$ with an $\mathrm{R}^{2}$ value of 0.9997 . Accuracy and precision (\%CV) of the calibration standards determined by back calculation ranged from 99.08 to $108.23 \%$ and 1.02 to $7.89 \%$, respectively.

\section{Accuracy}

Method accuracy was determined by back calculating the concentrations for six replicates of the QC samples (Table 1). The percentage accuracy ranged from 94.02 to $103.62 \%$. The accuracy levels were well within the acceptance limit of $\pm 15 \%$ for LQC, MQC, and HQC.

\section{Precision}

The precision of the chromatographic method was determined at intra-batch and inter-batch levels. For intrabatch precision determined by injecting various sets of QC samples within the same day, the values for the coefficient of variance (CV) ranged from 3.05 to $7.48 \%$. The inter-batch precision of the QC samples was assessed on different days, and the values for $\mathrm{CV}$ ranged from 2.61 to $6.34 \%$. The results of the precision studies, shown in Table 1, complied with the acceptance limits $(\% \mathrm{CV}<15)$ which demonstrates the repeatability of the method.

\section{Extraction recovery}

The efficiency of the method of drug extraction was determined, and the results are shown in Table 2. The mean drug recovery from the plasma was observed to range from 98.39 to $99.74 \%$ at the three QC levels, which indicates the efficiency of the sample extraction technique. The drug recovery is comparable with the methods reported previously (Acharjya et al. 2012; AlShehri et al. 2019).

Table 2 Recovery data for LTZ in rat plasma

\begin{tabular}{llll}
\hline QC level & Mean conc. detected $(\boldsymbol{\mu} \mathbf{g} / \mathbf{m L})$ & Recovery (\%) & RSD (\%) \\
\hline LQC & 0.212 & 98.39 & 2.59 \\
MQC & 0.994 & 99.74 & 3.46 \\
HQC & 7.651 & 98.86 & 2.56 \\
\hline
\end{tabular}

HQC high quality control, MQC middle quality control, LQC low quality control, $R S D$ relative standard deviation
Table 3 Stability studies of LTZ in rat plasma

\begin{tabular}{lllll}
\hline $\begin{array}{l}\text { QC } \\
\text { level }\end{array}$ & \%RE & & & \\
\cline { 2 - 5 } & $\begin{array}{l}\text { Freeze-thaw } \\
\text { stability }\end{array}$ & $\begin{array}{l}\text { Bench-top } \\
\text { stability (6 h) }\end{array}$ & $\begin{array}{l}\text { Autosampler } \\
\text { stability (10 h) }\end{array}$ & $\begin{array}{l}\text { Short-term } \\
\text { stability }\end{array}$ \\
\hline LQC & -10.73 & -6.32 & -3.08 & -2.17 \\
HQC & 2.34 & 3.30 & 2.98 & 4.71 \\
\hline
\end{tabular}

HQC high quality control, LQC low quality control, $R E$ relative error

\section{Stability studies}

The stability of LTZ in the plasma was assessed, and the data is shown in Table 3. The percentage relative error (\%RE) for the QC stability samples was determined by evaluating the mean accuracy of the back calculated concentrations. LTZ was observed to be stable following three cycles of freeze-thaw of the QC samples. The results of the benchtop stability (for $6 \mathrm{~h}$ ) and autosampler stability (for $10 \mathrm{~h}$ ) also indicated that LTZ was stable under these conditions. Short-term stability studies carried out for 7 days with the QC samples demonstrated that the results were well within the acceptance limits of $\pm 15 \%$. In addition, standard stock solutions of LTZ and CBZ were observed to be stable when kept on benchtop with $\% \mathrm{RE}<1.5 \%$.

\section{Pharmacokinetic studies}

The optimized method was applied to determine the pharmacokinetic parameters for LTZ following oral administration. The Winonlin software was used to calculate the parameters, and data is shown in Table 4. The mean plasma concentration of LTZ versus time profile in rat plasma is shown in Fig. 4. Oral gavage of LTZ in rats resulted in a peak plasma concentration of $\left(\mathrm{C}_{\max }\right)$ of $0.415 \pm 0.036 \mu \mathrm{g} / \mathrm{mL}$ and exhibited $\mathrm{T}_{\max }$ at $44.000 \pm$ $9.798 \mathrm{~h}$. The $\mathrm{AUC}_{(0-72)}$ was observed to be $25.007 \pm$ $1.425 \mu \mathrm{g} \mathrm{h} / \mathrm{mL}$ while $\mathrm{AUC}_{(0-\infty)}$ was observed to be $52.541 \pm 2.46 \mu \mathrm{g} \mathrm{h} / \mathrm{mL}$. The elimination rate constant $\left(\mathrm{K}_{\mathrm{el}}\right)$ was observed to be $0.011 \pm 0.001 / \mathrm{h}$. LTZ exhibited a mean residence time (MRT) of $101.900 \pm 7.316 \mathrm{~h}$ and

Table 4 Pharmacokinetic parameters of LTZ in SD rats following oral administration

\begin{tabular}{|c|c|}
\hline Parameters & Observed values* \\
\hline$\overline{K_{e l}}\left(h^{-1}\right)$ & $0.011 \pm 0.001$ \\
\hline$t_{1 / 2}(h)$ & $60.573 \pm 3.018$ \\
\hline$C_{\max }(\mu \mathrm{g} / \mathrm{mL})$ & $0.415 \pm 0.036$ \\
\hline $\mathrm{T}_{\max }(\mathrm{h})$ & $44.000 \pm 9.798$ \\
\hline$A \cup C_{(0-t)}\left(\mu \mathrm{ghmL} L^{-1}\right)$ & $25.007 \pm 1.425$ \\
\hline $\mathrm{AUC}_{(0-\infty)}\left(\mu \mathrm{g} \mathrm{h} \mathrm{mL^{-1 } )}\right.$ & $52.541 \pm 2.460$ \\
\hline MRT (h) & $101.900 \pm 7.316$ \\
\hline
\end{tabular}




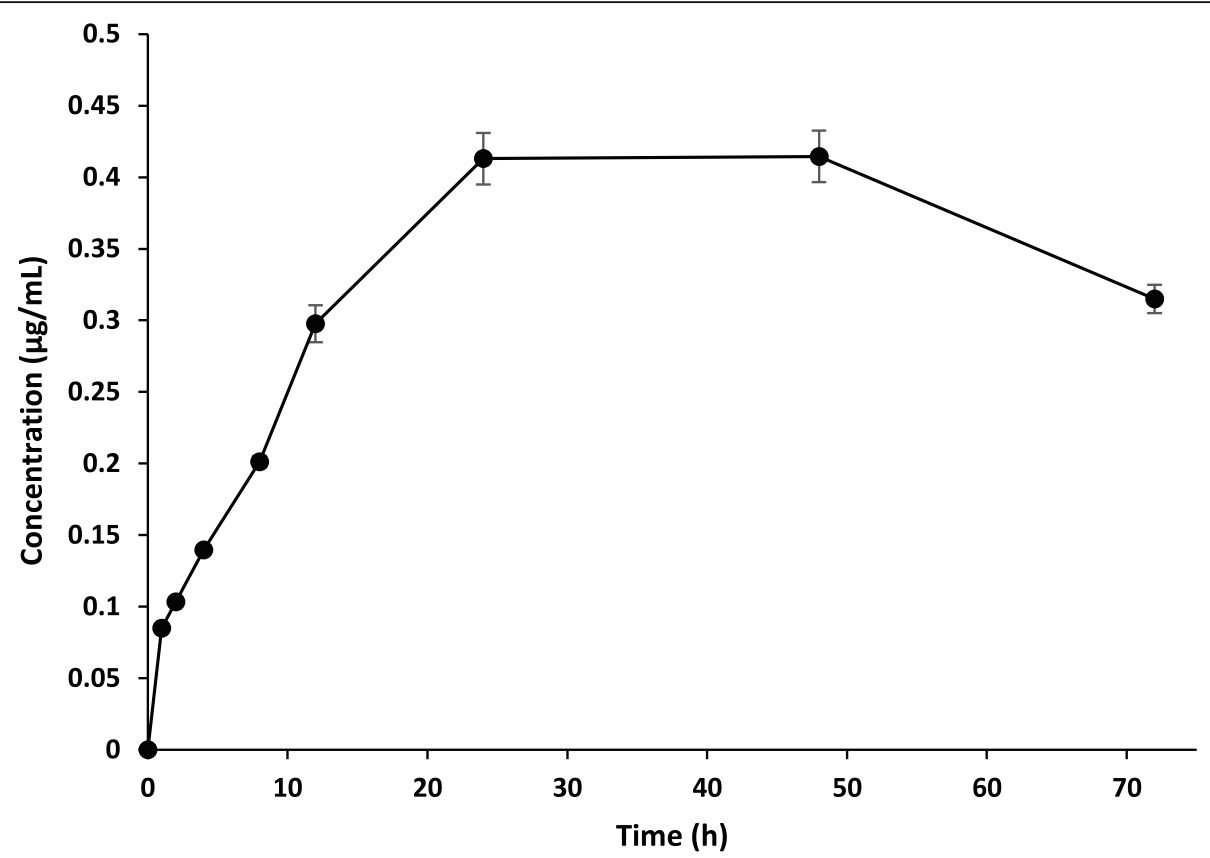

Fig. 4 Mean plasma concentration—time profile of LTZ in SD rats following oral administration $(n=6$; dose $=2 \mathrm{mg} / \mathrm{kg}$ ). Values are expressed as mean \pm S.D.

$t_{1 / 2}$ equivalent to $60.573 \pm 3.018 \mathrm{~h}$. These results are in close agreement with the results reported previously for oral administration of LTZ (Wempe et al. 2007; Dhakne et al. 2020). This clearly demonstrates the appropriateness of the chromatographic method to estimate LTZ in rat plasma.

\section{Conclusion}

A precise and sensitive reverse phase liquid chromatographic method was developed to quantify LTZ in rat plasma. Drug extraction from the plasma was carried out using a simple protein precipitation technique without the need of additional processing steps. The optimized method was validated according to the USFDA guidelines for the recommended validation parameters. The results of the validation study demonstrated that the developed method was precise, accurate, and sensitive over a wide linear range of LTZ concentrations in rat plasma. The applicability of the method was corroborated following oral administration of LTZ to determine the pharmacokinetic parameters

\section{Abbreviations}

RP: Reverse phase; HPLC: High-performance liquid chromatography; ACN: Acetonitrile; Al: Aromatase inhibitor; LTZ: Letrozole; USFDA: United States Food and Drug Administration; ElA: Enzyme immunoassay; UV: Ultraviolet; MS: Mass spectrometry; SD: Sprague-Dawley; S.D.: Standard deviation; OPA: Orthophosphoric acid; IS: Internal standard; CBZ: Carbamazepine; PA: Paracetamol; KCZ: Ketoconazole; LQC: Low quality control; MQC: Middle quality control; HQC: High quality control; MTBE: Methyl tertbutyl ether; LLOQ: Lower limit of quantification; QC: Quality control; RT: Room temperature

\section{Supplementary Information}

The online version contains supplementary material available at https://doi. org/10.1186/s40543-021-00276-4.

Additional file 1. Method optimization - effect of mobile phase compositions and internal standard (IS). Fig. S1. Effect of mobile phase composition and PA (IS). Chromatograms of a) diluent, b) LTZ, c) PA, d) blank plasma and e) spiked plasma using ACN and acetate buffer $\mathrm{pH} 4.5$ $(50: 50 \% \mathrm{v} / \mathrm{v})$ at $0.8 \mathrm{~mL} / \mathrm{min}$. Fig. S2. Effect of mobile phase composition and KCZ (IS). Chromatograms of a) diluent, b) LTZ, C) KCZ, d) blank plasma and e) spiked plasma using ACN and phosphate buffer $\mathrm{pH} 5.5$ $(65: 35 \% \mathrm{v} / \mathrm{v})$ at $0.8 \mathrm{~mL} / \mathrm{min}$.

\section{Acknowledgements}

The authors are thankful to Gland Pharma Ltd., Malur, Karnataka, India for providing gift sample of letrozole. The authors express their sincere thanks to (i) All India Council for Technical Education (AICTE), Government of India, New Delhi (for National Doctoral Fellowship to Bharath S Padya) and (ii) Department of Science and Technology, Government of India, New Delhi (for DST-INSPIRE Junior Research Fellowship to Soji Soman). The authors are grateful to Manipal College of Pharmaceutical Sciences, Manipal Academy of Higher Education, Manipal, for providing the necessary facilities.

\section{Authors' contributions}

All authors have equal contribution to this research work. All authors read and approved the final manuscript.

\section{Funding}

Not applicable

Availability of data and materials

Not applicable

\section{Declarations}

Competing interests

The authors declare that they have no competing interests. 
Received: 13 March 2021 Accepted: 24 May 2021

Published online: 11 June 2021

\section{References}

Acharjya SK, Bhattamisra SK, Muddana BR, Bera RV, Panda P, Panda BP, et al. Development of a high-performance liquid chromatographic method for determination of letrozole in Wistar rat serum and its application in pharmacokinetic studies. Sci Pharm. 2012;80(4):941-53. https://doi.org/10.3 797/scipharm.1206-06.

Al-Shehri M, Hefnawy M, Abuelizz H, Alzamil A. Evaluation of the pharmacokinetics of the simultaneous quantification of letrozole and palbociclib in rat plasma by a developed and validated HPLC-PDA. Acta Chromatogr. 2019:32:1-9.

Berzas JJ, Rodriguez J, Contento AM, Cabello MP. Determination of drugs used in advanced breast cancer by capillary gas chromatography of pharmaceutical formulations. J Sep Sci. 2003;26(9-10):908-14. https://doi.org/10.1002/jssc.2 00301334.

Bylda C, Thiele R, Kobold U, Volmer DA. Recent advances in sample preparation techniques to overcome difficulties encountered during quantitative analysis of small molecules from biofluids using LC-MS/MS. (Minireview). Analyst. 2014;139:2265-76.

Chumsri S, Howes T, Bao T, Sabnis G, Brodie A. Aromatase, aromatase inhibitors, and breast cancer. J Steroid Biochem Mol Biol. 2011;125(1-2):13-22. https:// doi.org/10.1016/j.jsbmb.2011.02.001.

Dhakne P, Sahu AK, Sharma MK, Sengupta P. Simultaneous quantification of abemaciclib and letrozole in rat plasma: method development, validation and pharmacokinetic application. Biomed Chromatogr. 2020;34:e4825.

Ganesh M, Kamalakannan K, Patil R, Upadhyay S, Srivatsava A, Sivakumar T, et al. A validated UV spectrophotometric method for the determination of letrozole in bulk and solid dosage form. Rasyan J Chem. 2008:1:55-8.

Ganesh M, Shrivastava A, Shrivastava V, Sivakumar T. UV-spectrophotometric determination of letrozole in tablet dosage form. Pharmacist. 2007:2:17-8

Hegde AR, Managuli RS, Naha A, Koteshwara KB, Reddy MS, Mutalik S. Full factorial experimental design for development and validation of a RP-HPLC method for estimation of letrozole in nanoformulations. Curr Pharm Anal. 2018;14(3):320-30. https://doi.org/10.2174/1573412913666171006152604.

Hegde AR, Rewatkar PV, Manikkath J, Tupally K, Parekh HS, Mutalik S. Peptide dendrimer-conjugates of ketoprofen: synthesis and ex vivo and in vivo evaluations of passive diffusion, sonophoresis and iontophoresis for skin delivery. Eur J Pharm Sci. 2017;102:237-49. https://doi.org/10.1016/j.ejps.2017. 03.009.

Joshi C, Vishnubhatla S, Chakkirala S, Mannam S. Validation and application of a high performance liquid chromatography-tandem mass spectrometry assay for letrozole in human plasma. Asian J Pharm Clin Res. 2011;4:107-12.

Laha TK, Patnaik RK, Sen S. Reverse phase high performance liquid chromatographic method for the analysis of letrozole in pharmaceutical dosage forms. Indian J Pharm Sci. 2008;70(3):401-3. https://doi.org/10.4103/ 0250-474X.43019.

Managuli RS, Gourishetti K, Shenoy RR, Koteshwara KB, Reddy MS, Mutalik S. Preclinical pharmacokinetics and biodistribution studies of asenapine maleate using novel and sensitive RP-HPLC method. Bioanalysis. 2017;9(14): 1037-47. https://doi.org/10.4155/bio-2017-0069.

Mareck U, Sigmund G, Opfermann G, Geyer H, Thevis M, Schaenzer W. Identification of the aromatase inhibitor letrozole in urine by gas chromatography/mass spectrometry. Rapid Commun Mass Spectrom. 2005; 19(24):3689-93. https://doi.org/10.1002/rcm.2239.

Marfil F, Pineau V, Sioufi A, Godbillon SJ. High-performance liquid chromatography of the aromatase inhibitor, letrozole, and its metabolite in biological fluids with automated liquid-solid extraction and fluorescence detection. J Chromatogr B Biomed Appl. 1996;683(2):251-8. https://doi.org/1 0.1016/0378-4347(96)00118-1.

Marina ML, Garcia MA. Chromatography: liquid, micellar liquid chromatography. In: Wilson ID, editor. Encyclopedia of separation science: Academic Press; 2000. p. 726-37.

Mondal N, Pal TK, Ghosal SK. Development and validation of a spectrophotometric method for estimation of letrozole in bulk and pharmaceutical formulation. Pharmazie. 2007;62(8):597-8.

Osborne C, Tripathy D. Aromatase inhibitors: rationale and use in breast cancer. Annu Rev Med. 2005:56(1):103-16. https://doi.org/10.1146/annurev.med.56. 062804.103324
Pfister CU, Duval M, Godbillon J, Gosset G, Gygax D, Marfil F, et al. Development, application and comparison of an enzyme immunoassay and a highperformance liquid chromatography method for the determination of the aromatase inhibitor CGS 20267 in biological fluids. J Pharm Sci. 1994;83(4): 520-4. https://doi.org/10.1002/jps.2600830415.

Scott LJ, Keam SJ. Letrozole: in postmenopausal hormone-responsive early-stage breast cancer. Drugs. 2006;66(3):353-62. https://doi.org/10.2165/00003495-2 00666030-00010.

Stone JA. Sample preparation techniques for mass spectrometry in the clinical laboratory. In: Nair H, Clarke W, editors. Mass spectrometry for the clinical laboratory. first ed. London: Elsevier; 2017. p. 37-62. https://doi.org/10.1016/ B978-0-12-800871-3.00003-1.

U.S. Food and Drug Administration Guidance for Industry: Bioanalytical method validation (2018) U.S. Department of Health and Human Services, Food and Drug Administration. Accessed 10 Feb 2021.

Vanol PG, Singhal P, Shah PA, Shah JV, Shrivastav PS, Sanyal M. SPE-UPLC-MS/MS assay for determination of letrozole in human plasma and its application to bioequivalence study in healthy postmenopausal Indian women. J Pharm Anal. 2016;6(4):276-81. https://doi.org/10.1016/j.jpha.2016.05.004.

Wempe MF, Buchanan CM, Buchanan NL, Edgar KJ, Hanley GA, Ramsey MG, et al. Pharmacokinetics of letrozole in male and female rats: influence of complexation with hydroxybutenyl- $\beta$-cyclodextrin. J Pharm Pharmacol. 2007; 59(6):795-802. https://doi.org/10.1211/jpp.59.6.0006.

Zarghi A, Foroutan S, Shafaati A, Khoddam A. HPLC determination of letrozole in plasma using fluorescence detection: application to pharmacokinetic studies. Chromatographia. 2007;66(9-10):747-50. https://doi.org/10.1365/s10337-0070381-9.

\section{Publisher's Note}

Springer Nature remains neutral with regard to jurisdictional claims in published maps and institutional affiliations.

\section{Submit your manuscript to a SpringerOpen ${ }^{\circ}$ journal and benefit from:}

- Convenient online submission

- Rigorous peer review

- Open access: articles freely available online

High visibility within the field

- Retaining the copyright to your article

Submit your next manuscript at $>$ springeropen.com 